\title{
A perspective on marriages and civil unions in South Africa Part 2 - Civil unions
}

\author{
Coertzen, Pieter \\ Stellenbosch University \\ pc@sun.ac.za
}

\begin{abstract}
The article argues that churches/religions ought to fully accept homosexuals as full members with all the rights that go with that, and treat them with Christian love, compassion and respect. But it also argues that if homosexual members do not abide by the official viewpoints of the Church and do not comply with the church's requirements for membership and thereby threatens the faith identity of a church or a religion, church's and religions have the right to terminate the membership of such members. Church's and religions have a right to their faith viewpoint, to express that viewpoint and to expect from all their members to accept that viewpoint if they want to remain members of that church/religion. Just as churches and religions should show love and respect to homosexual members they can also expect from the homosexual members and outside pressure groups to respect the faith convictions of the church that the practising of homosexuality is in contradiction with what Scripture teaches in 1 Corinthians 6:9 and in many other parts of Scripture.
\end{abstract}

\section{Keywords}

Marriage, civil unions, Christian perspective, freedom of religion, freedom of association

The Civil Union Act 17 of 2006 provides a framework for people of the same gender to formalise and legalise their relationship through a civil union $^{1}$. Some argue that this act regulates only the monogamous union of

1 Skelton, A (Editor); Carnelly Marita (Editor); Human, Sonia; Robinson, J.A.; Smith, Bradley; Scott, Johan. 2011. Familiereg in Suid-Afrika. Oxford University Press, South Africa. 196-197 
two persons of the same gender. ${ }^{2}$ It is not always clear from the Act itself that it provides for heterosexual unions too. ${ }^{3}$ The law itself describes a civil union as "the voluntary union of two persons who are both 18 years of age or older, which is solemnised and registered by way of either a marriage or a civil partnership, in accordance with the procedures prescribed [in the Civil Union Act], to the exclusion while it lasts, of all others."4 A marriage or a partnership in accordance with the Civil Union Act has the same consequences as a marriage according to the Marriage Act. Any reference to the term "marriage", "man", "wife" "spouse" in any other law, including common law, includes a civil union or a party to a civil union. Furthermore there are unique prescriptions with regarding to the formal and material legal requirements for civil unions such as that an ex officio marriage officer or a religious marriage officer can conduct a civil union. The same requirements regarding blood and family relations apply to both marriages and civil unions. The Civil Union Act also allows for ex officio marriage officers to refuse conducting civil unions on grounds of conscience, religion and faith. ${ }^{5}$

The fact that the mentioned marriages and unions are regulated by law brings about that the persons in the relationship enjoy certain rights and duties with regard to matters like privacy, dwelling(s) and property(s), pension funds, medical aid schemes, insurance, the right to support. They also have rights and duties with regard to children, immigration, inheritance, subsistence, and compensation in case of injuries at work or of illness and protection against violence. ${ }^{6}$

2 Civil Union Act 17 of 2006

3 Skelton, A (Editor); Carnelly Marita (Editor); Human, Sonia; Robinson, J.A.; Smith, Bradley; Scott, Johan. 2011. Familiereg in Suid-Afrika. Oxford University Press, South Africa. 189.

4 Skelton, A (Editor); Carnelly Marita (Editor); Human, Sonia; Robinson, J.A.; Smith, Bradley; Scott, Johan. 2011. Familiereg in Suid-Afrika. Oxford University Press, South Africa. 189.

5 Skelton, A (Editor); Carnelly Marita (Editor); Human, Sonia; Robinson, J.A.; Smith, Bradley; Scott, Johan. 2011. Familiereg in Suid-Afrika. Oxford University Press, South Africa. 197.

6 Women's Legal Centre, 2007, Ken u regte, 'n Maklike gids tot huwelike en verhoudings. Kaapstad. Womens Legal Centre, Cape Town. 1-25. 
Before 27 April 1994, the law paid very little attention to alternative family structures because civil marriages were the only state recognised option available. The concept of Civil marriage had two key elements:

- A marriage was a monogamous relationship between heterosexual persons.

- It was civil in the sense that this type of marriage was sanctioned by the state in that it was conducted according to the Marriage Act.

In 1983 in Ismael $v$ Ismael the Appeal court declared a marriage to be "the legally recognized voluntary union for life of one man and one woman to the exclusion of all others while it lasts. ${ }^{7}$

The new Constitution of $1996^{8}$ with the Bill of Rights immediately had a drastic influence on the marriage situation in South Africa. This was especially through the equality clauses and the Equality Act. For the first time in South Africa every person could claim equality before the law and equal protection by the law. Apart from equality the Bill of Rights also prohibited unfair discrimination inter alia on grounds of race, religion and sexual orientation. A string of court cases followed in which the right of spouses were gradually extended to partners of the same sex. The Bill of Rights also prohibited unfair discrimination on grounds of sexual orientation. The implication of this was that in due course the judicial recognition of marriage as an exclusive heterosexual institution came under attack. Judicially it started in 2002 when a lesbian couple, Fourie and Bonthuys asked the High Court of the Transvaal in Pretoria, currently the Northern Gauteng High Court, for an order to force the Minister of the Interior to register their marriage in terms of the Marriage Act. When the high Court rejected the request the couple sought other routes to have their marriage legally recognised. Finally on 1 December 2005 the Highest Court in South Africa, the Constitutional Court, made a decision that paved the way for marriages between same sex couples to be legally registered. The highest Court ruled that the Common Law description of a marriage as a monogamous relationship between heterosexual persons was inconsistent with the Constitution and invalid to the extent that it did

7 Ismael v Ismael 1983 (1) SA 1006 (A).

8 SA Constitution, $1994 ; 1996$ 
not allow for same sex couples to enjoy the same status, advantages and responsibilities awarded through marriage to heterosexual couples. ${ }^{9}$ The Court also ruled that article 31(1) of the Marriage Act, which contains the marriage formula, is equally unconstitutional because it contained words like "husband" and "wife" instead of a gender-neutral term like "spouse"10. The court suspended its ruling for twelve months to give the legislator time to prepare the necessary legislation for same sex couples to get married ${ }^{11}$. Should that not happen within a year's time the Court ruled that article 30(1) of the marriage law must be read as if it provided for spouses to get married. ${ }^{12}$

On 30 November of 2006 the Civil Union Act of 2006 took effect. The aim of the act was to regulate the solemnization and registration of civil unions and to provide for the results of such unions. In the Act a civil union is described as "the voluntary union of two persons who are both older than 18 years of age or older, which is solemnised and registered by way of either a marriage or a civil partnership, in accordance with the procedures prescribed [in the Civil Union Act], to the exclusion while it lasts, of all other."13

The Constitutional Court also ruled that religious institutions would remain undisturbed in their ability to perform marriage ceremonies according to their own tenets, and thus if they wished to celebrate heterosexual marriages only. The principle of reasonable accommodation, and thereby in fact freedom of religion, could be applied by the state to ensure that civil marriage officers who had sincere religious objections to officiating at same sex marriages would not themselves be obliged to do so if this resulted in a violation of their conscience. ${ }^{14}$ With reference to the input of Christian Education the Court held the following: "The underlying problem in any open and democratic society based on human dignity, equality and freedom in which conscientious and religious freedom has to be regarded

9 Minister of Home Affairs v Fourie, p 102, (b)

10 Minister of Home Affairs v Fourie, p 102, (c)

11 Minister of Home Affairs v Fourie, p 103, (e)

12 Minister of Home Affairs v Fourie, p 102-103, (d-e)

13 Civil Union Act, art 1.

14 Minister of Home Affairs v Fourie, p 99. 
with appropriate seriousness, is how far such democracy can and must go in allowing members of religious communities to define for themselves which laws they will obey and which not. Such society can cohere only if all its participants accept that certain basic norms and standards are binding. Accordingly, believers cannot claim an automatic right to be exempted by their beliefs from the laws of the land. At the same time, the State should, wherever reasonably possible, seek to avoid putting believers to extremely painful and intensely burdensome choices of either being true to their faith or else respectful of the law. ${ }^{15}$

In the Dutch Reformed Church the General Synod of 2004 had a report before it regarding homosexuality. In the report the view was held that the bible is not a historical or scientific handbook that gave us "full knowledge" of every aspect of the reality. It was therefore the task of the church, while staying loyal to the confession that the Bible is the Word of God, to consider how Scripture must be interpreted in a specific time. This resulted in a new report about homosexuality that had to be brought before synod - this report had to contain the views of experts, members with a homosexual orientation as well as the opinions of members who had been freed from homosexuality. Synod was asked to take note of the fact that there is not unanimity in the Church about homosexuality. Synod was also asked to consider whether the negative views about homosexuality in Scripture can be applied to homosexuality in general and specifically to homosexuals in permanent relationships of love and trust. It was stated before Synod that all persons, apart from their sexual orientation where objects of God's love and they should be accepted as full members of the church only on ground of their faith. All homosexual as well as heterosexual promiscuity were condemned and an unequivocal apology was made to all homosexuals and their families where the love of God was not made visible in the church's treatment of them in the past. ${ }^{16}$

In the years after 2004 the Dutch Reformed Church and other churches in South Africa has often been taken to task because of their view on homosexuality and same sex marriages. In some cases it was homosexual

15 Minister of Home Affairs v Fourie, p 99.

16 See: Strauss, P 2013. Kerkwees in die Branding. Die Nederduitse Gereformeerde Kerk in algemene sinodale verband 1994-2011. (Manuskrip) 
persons who threatened to take the churches to court for discrimination against them in not allowing them to the preaching office in the church or for not recognising their same sex marriages, or for dismissing a homosexual employee of the church. They claim that the attitude of churches and religions towards homosexual persons and against Civil Unions and the exclusion of them are/is a violation of their human rights. According to Pieter Cilliers, author of ' $n$ Kas is vir Klere (1997) and recently translated as Pilgrim (20013), it is a fight between human rights and equality on the one hand and religious rights on the other hand and the fact that religions claim that it is their right to discriminate against homosexual persons. ${ }^{17}$ Apparently they do not want to recognise the rights of religions in this regard.

During the same years that the discussion continued in churches in South Africa and in the same year that the Fourie case was heard the South African Human Rights Commission of South Africa (SAHRC) conducted a public enquiry in 2005 after they received complaints alleging violations of the rights to equality and dignity from persons excluded from joining voluntary associations. The purpose of the enquiry into equality and voluntary associations was to enable the SAHRC to hear representations of all interested parties and to reflect on the relevant constitutional and statutory provisions in order to suggest a set of principles that would achieve an appropriate balance between associational rights and the rights of equality and dignity. The context of the enquiry required the balancing of two distinct sets of rights. On the one hand there are the fundamental rights to be treated equally, not to be unfairly discriminated against and the rights to dignity on the other hand there are the cluster of rights sometimes collectively called associational rights which include the right to freedom of religion, freedom of association, freedom to practice and use one's language and culture and the right to associate in cultural, religious and linguistic communities.

In the end the SAHRC recommended that Voluntary Associations (VA's) who wanted to implement exclusionary policies had to take certain guidelines or legal principles into account. A church or a religion that sets

17 Die Burger, BY, Saterdag 8 Junie 2013. p 3. 
up rules of not allowing practising homosexuals into the preaching office, or not to employ them, or refusing to acknowledge civil unions would be good examples of such VA's. The guidelines they recommended are that:

1. The VA identify the right or interest that it seeks to protect like the faith identity or the spirituality of the church.

2. Identify the rights that may be infringed or limited by the adoption of a certain policy like the constitutional rights of practising homosexuals in terms of art 9(3) of the Constitution.

3. Determine alternative ways of achieving its objectives.

4. Adopt the alternative that achieves its objectives without unreasonably and unfairly limiting or restricting rights.

5. Maintain reasons as to why a particular method or means was adopted and other alternatives discarded or disregarded. ${ }^{18}$

This would mean that proper decisions would be made at the outset and reflect the necessary deliberation and balancing that needs to be done in order to derive at a constitutionally permissible conclusion. ${ }^{19}$

One of the oral presentations that were made was that of professor Woolman who made his presentation in his personal capacity and on behalf of the South African Board of Jewish Education (SABJE). Much of what he said can also be applicable for churches and religions in SA in their relationship to Civic Unions and Lifelong partnerships. In his presentation he said: ${ }^{20}$ "All the schools controlled by the SABJE are, in terms of the South African Schools Act designated as independent schools. The SABJE has a history of allowing non-Jewish children to attend their schools and employing nonJewish educators. Their schools however insist that all students admitted to the schools must adhere to and abide by the requirements of a Jewish education, undertake Hebrew language instructions, observe Jewish

18 The Exclusionary Policies of Voluntary Associations: Constitutional Considerations. 2006. p 31. South African Human Rights Commission. www.sahrc.org.za

19 The Exclusionary Policies of Voluntary Associations: Constitutional Considerations. 2006. p 31. South African Human Rights Commission. www.sahrc.org.za

20 The Exclusionary Policies of Voluntary Associations: Constitutional Considerations. 2006. pp 7-8. South African Human Rights Commission. www.sahrc.org.za 
religious instructions and participate in all school sponsored religious events. The application forms make it clear that the goals of the schools are to inculcate respect for the Jewish religion, its traditions, customs and institutions and to further the Zionist aims of the Jewish people. Parents and pupils admitted to the schools are required to abide by the policies and participate in all activities of the school. Thus, while the SABJE schools do not exclude non-Jewish children and non-Jewish educators, their admission is controlled in order to maintain the Jewish identity of the school."

Prof Woolman contended firstly that the school's admission policies do not amount to unfair discrimination, and secondly that if there is differentiation on specified ground, the admission policy constitutes fair discrimination as it is grounded in the legitimate objectives of the SABJE and its schools."

He conceded that the admission policy, which provides that an applicant who refuses to take Hebrew classes or Jewish religious instructions should be refused admission, could be interpreted as either imposing indirect burdens or withholding benefits from a student on grounds of religion. If this is the case, then the differentiation is deemed to be discrimination, and according to section 9 of the Constitution and the Equality Act, the onus of proving fairness rests on the school. According to Prof Woolman the discriminatory admissions policy is necessary to achieve the object of SABJE of offering a Jewish education, including Hebrew language classes and Jewish religious instructions. He also pointed out that in the urban centre of Johannesburg, a child in a position to afford private school fees has a great array of options opened to him or her. There is no compulsion either directly or indirectly for non-Jewish children to seek admission to SABJE controlled schools."

Based on the decision of Van Dijkhorst J in Wittman $v$ Deutscher Schulverein, he concludes that the constitutional right to set up and run an independent school grounded in culture, language or religion inevitably includes the right to exclude students who do not wish to adhere to school requirements that are grounded in language, culture or religion. Given the clear choice enjoyed by non-Jewish children to attend other private schools, the restrictive admission policies impact marginally on their dignity. The restrictive admission policies are however necessary in order to preserve the cultural, and religious character of the schools. Professor Woolman 
also referred to whether SABJE could limit entrance of non-Jewish students in order to preserve its objectives. The question is hypothetical in respect of the operations of the SABJE schools but very pertinent for the purposes of the SAHRC report. Prof Woolman concluded that the only proper basis for a completely exclusionary practice would be to prevent "capture". He defined capture as the legitimate fear that the new members of the community could, after having obtained sufficient numbers, move to fundamentally alter the character of the school. ${ }^{21}$

As can be seen from the above in any discussion about homosexuality and same sex relationships there are always two sets of human rights on the table. On the one hand the right to human dignity and equality - the right of a person not to be discriminated against ${ }^{22}$ and an inherent right to dignity and that the dignity be recognised and respected and protected. ${ }^{23}$ On the other hand there is the right to freedom of conscience, religion, thought, belief and opinion ${ }^{24}$ and the right of each person to freedom of association. ${ }^{25}$ These two sets of fundamental rights do not stand in a hierarchical order but are on an equal footing with each other. ${ }^{26}$

The right to equality which entails the right not to be discriminated against as well as the right to inherent human dignity and that that dignity should be respected and protected are indeed fundamental human rights that churches must also respect and treat in the love of Christ. Because equality and human dignity are rights, which are included in the Bill of Rights, it is the duty of the State to see to it that these rights are not neglected in important areas of the life of citizens like the workplace. Work enables people to feed themselves as well as those who are dependent of them, it also enhances one's feeling of wellbeing and self esteem, assisting in lowering levels of depression. A person's right to labour should in normal

21 See also Lenta, P 2012. The Right of religious Associations to Discriminate. In: South African Journal of Human Rights, Vol 28, Issue 2, p 249-250.

22 The Constitution of the Republic of South Africa. Act 108 of 1996. Art 9(3).

23 The Constitution of the Republic of South Africa. Act 108 of 1996. Art 10.

24 The Constitution of the Republic of South Africa. Act 108 of 1996. Art 15.

25 The Constitution of the Republic of South Africa. Act 108 of 1996. Art 18.

26 Lenta, P 2009. Taking Diversity Seriously: Religious Associations and Work Related Discrimination. In: South African Law Journal, p 126, pp 834-836. 
circumstances not be dependent on matters like race, gender, sexual orientation or religion. ${ }^{27}$

But just as important and equal to the rights of equality and dignity is the right to freedom of association and freedom of religion. ${ }^{28}$ Both these rights must also be treated with respect in churches in the love of Christ. ${ }^{29}$ The state must also respect, protect, promote and fulfil the right to freedom of religion and freedom of association. ${ }^{30}$

Freedom of association is important because groups and associations with whom a person associates play a very important role in the wellbeing of an individual as well in the lives of the persons with whom the individual associates. The right to freedom of association enables an individual or an association of individuals to engage in and to keep intimate relations of love and friendship. Such associations are very important as ways in which charity, commerce and industry, education, health care, neighbourliness and also religion can be exercised. Freedom of association is also a very important part of individual freedom because associations reflect the choices of their members about how they want to live, which they want to associate with and what they want to believe. ${ }^{31}$ Freedom of association also underlines the importance of civil society - that network of intimate, meaningful and associational institutions which stand between the individual and the state and which helps the individual(s) to counter any dominance by either the state or a section within an association. ${ }^{32}$

27 Lenta, P 2009. Taking Diversity Seriously: Religious Associations and Work Related Discrimination. In: South African Law Journal, p 831.k

28 Lenta, P 2009. Taking Diversity Seriously: Religious Associations and Work Related Discrimination. In: South African Law Journal, p 831.

29 Lenta, P 2009. The Right of Religious Associations to Discrminate. In: South African Journal of Human Rights, vol 28(2):241.

30 The Constitution of the Republic of South Africa. Act 108 of 1996. Art. 7(3)

31 Lenta, P 2005. Religious Libery and Cultural Accomodation. In: South African law Journal, p 362.

32 Lenta, P 2012. The Rights of religious Associations to Discriminate. In: South African Journal of human Rights, Vol 28(2):241. 
It has often been acknowledged by scholars ${ }^{33}$ as well as by courts worldwide that the extension and application of certain public principles and laws to certain associations need to be restricted. Exactly this is what makes that freedom of association must be protected meticulously. ${ }^{34}$ In Roberts $v$ United States Jaycees (468 US 609 (1984)) ${ }^{35}$ Brennan J names the following as some of the most important reasons why the right to freedom of association must be protected:

- Freedom of association is a fundamental element of human freedom that enables matters like freedom of speech, freedom of assembly and the free exercise of religion.

- Freedom of association has played a very important role in the cultivation and transmission of shared ideals and beliefs.

- Freedom of association is a critical barrier between the individual or an association like a church and the power of the state.

- Freedom of association is also a source of empowerment for individuals who draw their emotional strength from close ties that are forged with others in associations.

- Lastly freedom of associations safeguards the ability to define one's identity independently and this freedom and identity is central to any concept of liberty. ${ }^{36}$

Freedom of association is also very closely connected to diversity. Lenta quotes Galston who argued that "properly understood, liberalism is about the protection of diversity". ${ }^{37}$ In a liberal state there exists associations embodying contrasting conceptions of the good life and differing views on

33 Lenta, P The Rights of religious Associations to Discriminate. In: South African Journal of human Rights, Vol 28(2):236.

34 Lenta, P 2012. The Rights of religious Associations to Discriminate. In: South African Journal of human Rights, Vol 28(2):235.

35 See: Lenta, P 2009. Taking Diversity Seriously: Religious Associations and Work Related Discrimination. In: South African Law Journal, p 126, pp 834-836.

36 Lenta, P 2009. Taking Diversity Seriously: Religious Associations and Work Related Discrimination. In: South African Law Journal, p 832.

37 Lenta, P 2009. Taking Diversity Seriously: Religious Associations and Work Related Discrimination. In: South African Law Journal, p 832. 
what constitutes worthy goals. ${ }^{38}$ Brennan J writes about “An individual's freedom to speak [and] to worship ... could not be vigorously protected from interference by the State unless a correlative freedom to engage in a group effort toward those ends were not also guaranteed. According protection to collective effort on behalf of shared goals is especially important in preserving political and cultural diversity." 39

It cannot always be expected from religious associations to conform to public principles and legislation such as non-discrimination when those principles and legislation clash with the convictions of members of an association. The state should therefor refrain as far as possible from interfering with the internal affairs of associations, as protection of diversity requires. ${ }^{40}$

Religions and religiously administered institutions are not mere institutions. Religious institutions and their claim to be allowed association in their internal affairs and in the workplace, to discriminate on otherwise prohibited grounds like gender and sexual orientation is grounded in freedom of religion and freedom of association. ${ }^{41}$ Freedom of religion implies that churches and other religious organisations have the right to organise their own internal affairs according to their faith convictions. They have the authority to decide on their own affairs and this authority should be free from intervention by the state, or any other body in society. It is unacceptable that a state or society can insist that religious institutions conduct their affairs in a manner which is prescribed by the state and which is in contradiction with their faith convictions and practices.

38 Lenta, P 2009. Taking Diversity Seriously: Religious Associations and Work Related Discrimination. In: South African Law Journal, p 832.

39 Brennan J Roberts v United States, [Jaycees 468 US 622 (1984)]. Lenta, P 2009. Taking Diversity Seriously: Religious Associations and Work Related Discrimination. In: African Law Journal, p 832.h

40 Brennan J Roberts $v$ United States, Jaycees 468 US 622 (1984) Lenta, P 2009. Taking Diversity Seriously: Religious Associations and Work Related Discrimination. In: African Law Journal, p 833; Lenta, P 2012. The Right of Religious Associations to Discriminate. In: South African Journal of Human Rights, Vol 28(2):245.

41 Lenta, P 2009. Taking Diversity Seriously: Religious Associations and Work Related Discrimination. In: South African Law Journal, p 833. 
The right to equality, dignity, and freedom of religion and freedom of association are four fundamental human rights. Religion is a very important part of the life of religious persons and their search for the ultimate meaning in life. The right to freedom of religion protects and enables persons to find the definitive values for their life and to live that life together with other people who think and confess like they do. ${ }^{42}$ Religion is a source of identity for people and for their self-respect and dignity. Religion is therefor also a source of moral values for the individual, coreligionists as well as for society. When the claims to freedom of religion are added to the rights of freedom of association it often happens that the right of religious associations to be acquitted from anti-discrimination laws trumps the claims of non-religions associations.

Freedom of religion and freedom of association are both not absolute rights just as the right to equality or non-discrimination and human dignity are also not absolute rights. ${ }^{43}$ At times the right to freedom of religion and freedom of association have to make way for the right of non-discrimination, while at other times the right to equality or non-discrimination must give in to the right of freedom of religion and freedom of association. In the end it must be a matter of the balancing of the two sets of rights The question of whether the state should be allowed to subject religious institutions to such substantial burdens that it can affect their key religious convictions will depend on the extent to which there is tampered with key religious convictions and also the power of the state's justification to get involved.

Churches that do not allow the free exercise of homosexuality are often accused of being without love, and of not recognising the Constitutional rights of homosexuals and of being fundamentalist in their theology. There are even those who question whether freedom of religion is a human right. From their point of view churches actually do not have a right to take a view against homosexualism. For them the dispute is between the human rights of equality and dignity on the one hand and religious rights on the other hand and the fact that religions claim the right to discriminate. It is

42 Lenta, P 2009. Taking Diversity Seriously: Religious Associations and Work Related Discrimination. In: South African Law Journal, p 833.

43 Lenta, P 2009. Taking Diversity Seriously: Religious Associations and Work Related Discrimination. In: South African Law Journal, p 834. 
an issue of human rights versus religious rights. ${ }^{44}$ The implication of this kind of argument is clear - churches do not have a choice but to fully accept homosexualism because it is a human right while freedom of religion is not a human right. This kind of argumentation is wrong. Both the rights of equality and dignity as well as the rights of religious freedom and freedom of association are fully and equally sets of human rights. On the grounds of the right to freedom of religion and freedom of association a church as well as a religious institution have the fullest right to state their view on homosexualism and to expect from their members to comply with that view. The right to equality and human dignity as well as the right to freedom of religion and freedom of association must be recognised and respected by all involved in any discussion on homosexuality and civil unions.

It is very important for churches and religions to make very sure of their position on marriage and civil unions because of the on-going debate in South Africa about marriage and civil unions. In our times there are voices calling for the repealing of the Marriage Act in order to overcome the possibility of the unconstitutionality of some provisions in the Civil Union Act. Other scholars suggest that the Marriage Act be amended to apply to both same-sex as well as heterosexual couples alike. Churches and religions can only make a meaningful contribution to these debates if they are sure of their own position on these matters. ${ }^{45}$

The scene of marriage has changed a lot in South Africa since the new Constitutional dispensation of 1994/1996. The relationship between religion and marriages has certainly been loosened and it is now much more the responsibility of churches and religions to nurture and maintain the religious character of marriage. Churches must also clearly avail themselves of the fact that all religions, and not only the Christian religion can now claim the rights and responsibilities brought about by the Constitution. Furthermore every church and religion now has freedom of religion, this places a big responsibility on Churches and other religions to avail themselves of what their theological roots with regard to marriage is and to see to it that those convictions are expressed and practised in their

44 Die Burger, BY. 8 Junie 2013, p 3.

45 Heaton, Jaqueline 2010. South African Family Law (Third Edition), Lexis Nexis, South Africa, pp 201-202. 
marriage formulas and church orders. Churches and religions also have the responsibility to see to it that the members of the church or the religion comply with the viewpoints of the church. If this does not happen and nothing is done about it will end up that the courts will determine the view that is taken with regard to marriage in South Africa.

Another big change in the South African Society is the Civil Union Act 17 of 2006 that for the first time in the history of South Africa provided a framework for people of the same gender to formalise and legalise their relationship through a civil union. For churches and religions this brought forward very strongly the question of the position of homosexual people in a church/religion and whether they should participate in the practise of civil unions.

Some people have thus far argued very strongly that churches/religions do not have a choice but to fully accept practicing homosexuals and their unions in the church/religion and not discriminate against them in anyway.

Above it has been argued that churches/religions ought to fully accept homosexuals as full members with all the rights that go with that, and treat them with Christian love, compassion and respect. But if the homosexual members do not abide by the official viewpoints of the Church and do not comply with the church's requirements for membership and thereby threatening the faith identity of a church or a religion church's and religions have the right to terminate the membership of such members. Church's and religions have a right to their faith viewpoint, to express that viewpoint and to expect from all their members to accept that viewpoint if they want to remain members of that church/religion. Just as churches and religions should show love and respect to homosexual members they can also expect from the homosexual members and outside pressure groups to respect the faith convictions of the church that the practising of homosexuality is in contradiction with what Scripture teaches in 1 Corinthians 6:9 and in many other parts of Scripture. 


\section{Bibliography}

Brennan J Roberts v United States Jaycees 468 US 622 (1984) In: Lenta, P. Taking Diversity Seriously: Religious Associations and Work Related Discrimination. African Law Journal, 2009:832.h

Civil Union Act 17 of 2006

Die Burger, BY, Saterdag 8 Junie 2013:3.

Heaton, Jaqueline 2010. South African Family Law (Third Edition), Lexis Nexis: South Africa. 201-202.

Ismael v Ismael 1983 (1) SA 1006 (A).

Lenta, P, Religious Libery and Cultural Accomodation. South African law Journal, 2005:362.

Lenta, P 2012. The Right of Religious Associations to Discriminate. In: South African Journal of Human Rights, Vol 28, Issue 2:249-25h0.

Lenta, P 2009. Taking Diversity Seriously: Religious Associations and Work Related Discrimination. In: South African Law Journal, 126:834-836.

Minister of Home Affairs v Fourie, p102, (b)

SA Constitution, 1994; 1996.

Skelton, A (Editor); Carnelly Marita (Editor); Human, Sonia; Robinson, JA; Smith, Bradley; Scott, Johan. 2011. Familiereg in Suid-Afrika. Oxford University Press: South Africa. 196-197:

Strauss, P 2013. Kerkwees in die Branding. Die Nederduitse Gereformeerde Kerk in algemene sinodale verband, 1994-2011. (Manuskrip)

The Exclusionary Policies of Voluntary Associations: Constitutional Considerations, 2006:31. South African Human Rights Commission. www.sahrc.org.za

Women's Legal Centre, 2007. Ken u regte. 'n Maklike gids tot huwelike en verhoudings. Cape Town. 1-25. 